\title{
Working Capital Management in Small Enterprise -A Case Study of P L PLAST Pvt. Ltd
}

\author{
Dr.Venkateswararao.Podile ${ }^{1}$, Siva Sree.Chinta ${ }^{2}$ Prof.D.SuryachandraRao ${ }^{3}$ \\ ${ }^{\text {I}}$ (Professor, MBA Department, Andhra Loyola Institute of Engineering and Technology, India' \\ 2(Research Scholar, Department of Business Management, Krishna University, India) \\ 3(Professor, Department of Business Management, Krishna University, India)
}

\begin{abstract}
Small and Medium Enterprise (SME) are the biggest contributors to the economy of any country and the same goes with Indian economy. SMEs' success much depends upon effective working capital management. This paper deals with working capital management in P L Plast Pvt ltd, which is an Indian Small Enterprise of Nellore district in the state of Andhra Pradesh. It is an ISI certified company. In this paper an attempt is made to examine the structure and composition of working capital in the Enterprise during the period of study covering ten years from 2006-07 to 2015-16. An attempt is also made to analyze the liquidity position, to find the gross working and networking turnover and to examine the efficiency in cash, debtors and inventory management in the Small Enterprise under study.
\end{abstract}

Keywords: Cash Turnover, Debtors turnover, Inventory turnover, Liquidity, Small Enterprise

\section{Introduction}

Working Capital Management is concerned with the management of current assets and current liabilities and the inter relationship that existed between them. Efficient working capital management is essential for successful running of any company. Especially SMEs' success much depends upon effective working capital management.SME businesses are the biggest contributors to the economy of any country and the same goes with Indian economy. In fact, SME sector is one of the most crucial sectors of Indian economy as far as the number of employments generated. As more than 65 Percent of Indian population lives in rural and semi-rural areas, small business became a major source of income for many residing in these areas. P L Plast Pvt ltd. is an Indian Small Enterprise of Nellore district in the state of Andhra Pradesh. The Enterprise was started in the year 2002. It is an ISI certified company. The SME has an annual turnover of Rs.1, 13, 07,396. The Enterprise is manufacturing Agricultural pipes. The raw materials used in manufacturing the product are Polyvinyl Chloride (PVC) regime, Calcium, SA titanium, wax, Dioctyl Phthalate (DOP), Processing acids and Lubricants. The total Current Assets of the company are Rs.1, 48, 92,268 and the current liabilities are Rs. 50, 83,769. The company has a man power of 18 . The company advertises the products through news papers and flexes. The company has special vehicles to deliver the products to the customers. In this paper an attempt is made toexamine working capital management in P L PLAST Pvt Ltd.

\section{Review of literature}

Mishra (1975) $)^{1}$ studied the efficiency of working capital management in six sample public sector units. The study identified that management of various components of working capital in sample units was highly unsatisfactory. In addition, the condition of financing of working capital in sample units was also miserable. Suk, Seung and Rowland $(1992)^{2}$ in their research conducted an in-depth survey to analyze the liquidity practices of ninety four sample Japanese companies operating in the United States. Sivarama $(1999)^{3}$ in his study on working capital management in the Indian paper industry, found a close association between profitability and working capital efficiency. Reddy $(2000)^{4}$ analyzed the working capital management in thirty small scale industries in the Cuddapah district of Andhra Pradesh and found that debtor management policy and the collection mechanism to be very unsystematic and highly inefficient that resulted into excess investment in debtors. Ghosh and Maji (2003) $)^{5}$ made an empirical study on the relationship between utilization of current assets and operating profitability in the Indian cement and tea industries. Bardia (2004) ${ }^{6}$ conducted a study on the issue pertaining to the relationship between working capital management and profitability of a Navaratna steel manufacturing public sector enterprise. This study revealed a favorable influence of the liquidity of the company on its profitability. Prof. B.P.Singh (2012) ${ }^{7}$ investigated the relationship between the components of working capital and profitability. He observed that the telecom industry is operating below average so far as working capital is concerned. Pasupathi $(2013)^{8}$ conducted a comparative study of WCM performance in commercial vehicles, passenger cars and multi utility vehicles and 2 and 3 wheelers sectors of Indian automobile industry. Utkarsh Goel et al. (2015) ${ }^{9}$ conducted a study to explore the impact of corporate governance practices on Working capital Management (WCM) in Indian firms.S. Selvanayaki et al. $(2015)^{10}$ focused on evaluating 
the WCM practices adopted by the rice milling firms and analyzed its impact on profitability. It has been concluded that the WCM in milling firms was good and this also improved over years. It was found that there was no study on working capital management in a Small and Medium Enterprise in general and in a firm of India in particular. Hence, this study is taken up.

\title{
Objectives
}

The general objective of the study is to examine the working capital management in P L Plast Pvt Ltd. The specific objectives include the following.

1. To examine the structure and composition of working capital in P L Plast Pvt Ltd during the period of study.

2. To analyze the liquidity position of Small Enterprise during the period of study.

3. To find the gross working and networking turnover in the company.

4. To examine the efficiency in cash, debtors and inventory management in the SME under study.

5. To offer suggestions for effective working capital management if required.

\author{
Hypotheses \\ $\mathbf{H}_{01}$ : Current ratio in P L Plast Pvt Ltd is uniform during the period of study. \\ $\mathbf{H}_{\mathbf{0 2}}$ : Quick ratio in P L Plast Pvt Ltd is uniform during the period of study. \\ $\mathbf{H}_{03}$ : Super quick ratio in P L Plast Pvt Ltd is uniform during the period of study. \\ $\mathbf{H}_{04}$ : Gross working capital turnover ratio in P L Plast Pvt Ltd is uniform during the period of study. \\ $\mathbf{H}_{\mathbf{0 5}}$ : Net working capital turnover ratio in P L Plast Pvt Ltd is uniform during the period of study. \\ $\mathbf{H}_{06}$ : Cash turnover ratio in P L Plast Pvt Ltd is uniform during the period of study. \\ $\mathbf{H}_{07}$ : Inventory turnover ratio in P L Plast Pvt Ltd is uniform during the period of study. \\ $\mathbf{H}_{\mathbf{0 8}}$ : Debtors turnover ratio in P L Plast Pvt Ltd is uniform during the period of study. \\ $\mathbf{H}_{\mathbf{0}}$ : Average collection period in P L Plast Pvt Ltd is uniform during the period of study.
}

\section{Methodology}

The present study is mainly based on secondary data. The data is taken from the financial statements including balance sheet, trading account and profit and loss account of P L Plast Pvt Ltd. The period of study is ten years covering the financial years from 2006-07 to 2015-16.The data gathered is analyzed through the technique of percentages and certain appropriate ratios relating to working capital management. The ratios covered includes current ratio, quick ratio, super quick ratio, gross working capital turnover ratio, net working capital turnover ratio, cash turnover ratio, inventory turnover ratio, debtors turnover ratio and average collection period. Chi square test is used for testing the hypotheses formed.

\section{Analysis And Discussion of Results}

Working capital structure of P L Plast Pvt Ltd is presented in table1. It is observed that Inventory was 23 percent of total current assets during 2009. It is the lowest percentage during the period of study. Its percentage was highest at 91.31 during 2013. It is observed that inventory occupied highest percentage of current assets during the seven years of the study period except during 2008, 2009 and 2011. Debtors as a percentage of total current assets varied in between 6.39 during 2013 and 72.08 during 2009. Of all current assets debtors occupied highest percentage during 2008, 2009 and 2011.It is also observed that cash and bank balance as a percentage of current assets varied between 0.055 during 2010 and 16.26 during 2011. Loans and advances as a percentage of current assets varied between 2.51 during 2008 and 5.62 during 2011. They are nil during the last five years of the study. Other current assets as a percentage of total current assets is nil during the first five years of the study and during 2014. Their percentage varied between 0.073 during 2015 and 0.91 during 2012. Provisions are the only current liabilities during the first four years of the study. Provisions occupied 100 percent of current liabilities during first four years and also 98.73 percent during the next year. Surprisingly they are nil during the rest of the period. Sundry creditors as a percentage of total current liabilities occupied major share during the second half of the study period. They varied between 53.54 during 2013 and 93.55 during 2012. They are not found during the first half of the study period. We can found that the firm attained credit worthiness after ten years of its inception. Short-term borrowings by the firm were made during the last four years of the study. Short-term borrowings as a percentage of current liabilities varied between 14.67 during 2016 to 44.48 during 2013. Short-term provisions are maintained in the firm during 2013 and 2014 only. Short-term provision as a percentage of current liabilities was 0.8 during 2014 and is 1.84 during 2013. It is observed that Net Working Capital in the company varied between Rs.21.71 Lakhs during 2010 to Rs.111.2 Lakhs during 2015. It was maintained at high levels during the last six years of the study. 
Working Capital Management In Small Enterprise -A Case Study Of P L Plast Pvt. Ltd

(Figures in Lakhs)

Table 1: Working Capital structure of P L Plast Pvt. Ltd., Nellore

\begin{tabular}{|c|c|c|c|c|c|c|c|c|c|c|}
\hline Particulars & 2007 & 2008 & 2009 & 2010 & 2011 & 2012 & 2013 & 2014 & 2015 & 2016 \\
\hline \multicolumn{11}{|l|}{ Current Assets } \\
\hline Cash \& Bank balances & 2.71 & 2.01 & 0.65 & 0.032 & 14.72 & 3.22 & 1.75 & 10.76 & 18.65 & 4.20 \\
\hline$\%$ of TCA & 6.55 & 3.63 & 1.55 & 0.055 & 16.26 & 4.15 & 1.72 & 8.98 & 13.68 & 2.82 \\
\hline Debtors & 13.54 & 34.19 & 30.22 & 20.50 & 40.35 & 7.90 & 6.50 & 25.90 & 27.29 & 62.01 \\
\hline$\%$ of TCA & 32.76 & 61.74 & 72.08 & 35.70 & 44.59 & 10.19 & 6.39 & 21.62 & 20.02 & 41.63 \\
\hline Loans \& Advances & 1.39 & 1.39 & 1.39 & 1.59 & 5.09 & 0 & 0 & 0 & 0 & 0 \\
\hline$\%$ of TCA & 3.36 & 2.51 & 3.31 & 2.76 & 5.62 & 0 & 0 & 0 & 0 & 0 \\
\hline Other Current Assets & 0 & 0 & 0 & 0 & 0 & 0.71 & 0.58 & 0 & 0.10 & 0.20 \\
\hline$\%$ of TCA & 0 & 0 & 0 & 0 & 0 & 0.91 & 0.57 & 0 & 0.073 & 0.13 \\
\hline Inventory & 23.67 & 17.76 & 9.65 & 35.28 & 30.32 & 65.67 & 92.89 & 83.08 & 90.25 & 82.50 \\
\hline$\%$ of TCA & 57.28 & 32.07 & 23.0 & 61.45 & 33.50 & 84.72 & 91.31 & 69.37 & 66.21 & 55.39 \\
\hline $\begin{array}{l}\text { Total Current Assets } \\
\text { (TCA) }\end{array}$ & 41.32 & 55.37 & 41.92 & 57.41 & 90.49 & 77.51 & 101.7 & 119.7 & 136.3 & 148.9 \\
\hline \multicolumn{11}{|l|}{ Current Liabilities } \\
\hline Sundry Creditors & 0 & 0 & 0 & 0 & 0 & 4.21 & 8.98 & 19.30 & 18.05 & 43.18 \\
\hline$\%$ of TCL & 0 & 0 & 0 & 0 & 0 & 93.55 & 53.54 & 62.13 & 71.96 & 84.94 \\
\hline Provisions & 7.04 & 5.07 & 15.06 & 35.70 & 15.55 & 0 & 0 & 0 & 0 & 0 \\
\hline$\%$ of TCL & 100 & 100 & 100 & 100 & 98.73 & 0 & 0 & 0 & 0 & 0 \\
\hline Other current liabilities & 0 & 0 & 0 & 0 & 0.20 & 0.28 & 0 & 4.06 & 0.23 & 1.92 \\
\hline$\%$ of TCL & 0 & 0 & 0 & 0 & 1.26 & 6.22 & 0 & 13.07 & 0.91 & 3.77 \\
\hline Short term borrowings & 0 & 0 & 0 & 0 & 0 & 0 & 7.46 & 7.43 & 6.79 & 7.46 \\
\hline$\%$ of TCL & 0 & 0 & 0 & 0 & 0 & 0 & 44.48 & 23.92 & 27.07 & 14.67 \\
\hline Short term provisions & 0 & 0 & 0 & 0 & 0 & 0 & 0.31 & 0.25 & 0 & 0 \\
\hline$\%$ of TCL & 0 & 0 & 0 & 0 & 0 & 0 & 1.84 & 0.80 & 0 & 0 \\
\hline $\begin{array}{l}\text { Total Current } \\
\text { Liabilities (TCL) }\end{array}$ & 7.04 & 5.07 & 15.06 & 35.70 & 15.75 & 4.50 & 16.77 & 31.06 & 25.08 & 50.83 \\
\hline NWC & 34.28 & 50.3 & 26.86 & 21.71 & 74.74 & 73.01 & 84.95 & 88.69 & 111.2 & 98.09 \\
\hline
\end{tabular}

Source: Annual Reports of P L Plast Pvt Ltd. from 2006-07 to 2015-2016

The current ratio in the company was maintained at higher level in the company. It has varied between 1.6 during 2010 and 17.2 during 2012 as was shown in the table 2. The current ratio of the company showed wide fluctuations though maintained at high levels. It is found in the significance test that current ratio is not uniform during the period of study.

(Figures in Lakhs)

Table 2: Current Ratio

\begin{tabular}{|l|l|l|l|l|l|l|l|l|l|l|}
\hline Years & 2007 & 2008 & 2009 & 2010 & 2011 & 2012 & 2013 & 2014 & 2015 & 2016 \\
\hline Current Assets & 41.32 & 55.37 & 41.92 & 57.41 & 90.49 & 77.51 & 101.72 & 119.75 & 136.30 & 148.92 \\
\hline Current Liabilities & 7.04 & 5.07 & 15.06 & 35.70 & 15.55 & 4.50 & 16.77 & 31.06 & 25.08 & 50.83 \\
\hline Current ratio & 5.8 & 10.9 & 2.8 & 1.6 & 5.8 & 17.2 & 6.06 & 3.85 & 5.43 & 2.93 \\
\hline
\end{tabular}

Source: Annual Reports of P L Plast Pvt Ltd. from 2006-07 to 2015-2016

Calculated value of $\chi^{2}$ for current ratio $=30.931$

The Critical value of $\chi^{2}$ at 9 degrees of freedom at 5\% level of Significance is 16.919

Calculated value is greater than Critical Value i.e., 30.931>16.919, Hence, $\mathrm{H}_{01}$ is rejected.

The quick ratio of the company as shown in table 3 has varied between 0.52 during 2013 to 7.41 during 2008. It is found in the significance test that quick ratio is uniform during the period of study.

(Figures in Lakhs)

Table 3: Quick Ratio

\begin{tabular}{|l|l|l|l|l|l|l|l|l|l|l|}
\hline Years & 2007 & 2008 & 2009 & 2010 & 2011 & 2012 & 2013 & 2014 & 2015 & 2016 \\
\hline Liquid Assets & 17.65 & 37.60 & 32.26 & 22.13 & 60.17 & 11.84 & 8.83 & 36.66 & 46.05 & 66.42 \\
\hline Current Liabilities & 7.04 & 5.07 & 15.06 & 35.70 & 15.55 & 4.50 & 16.77 & 31.06 & 25.08 & 50.83 \\
\hline Quick Ratio & 2.50 & 7.41 & 2.14 & 0.6 & 3.86 & 2.62 & 0.52 & 1.18 & 1.83 & 1.31 \\
\hline
\end{tabular}

Source: Annual Reports of P L Plast Pvt Ltd. from 2006-07 to 2015-2016.

Calculated value of $\chi^{2}$ for Quick ratio $=15.48$

The Critical value of $\chi^{2}$ at 9 degrees of freedom at 5\% level of Significance is 16.919

Calculated value is less than Critical Value i.e., $15.48<16.919$, Hence, $\mathrm{H}_{02}$ is accepted.

The super quick ratio of the company as shown in the table 4 has varied between 0.0009 during 2010 and 0.946 during 2011. It is found in the significance test that super quick ratio is uniform during the period of study. 
(Figures in Lakhs)

Table 4: Super Quick Ratio

\begin{tabular}{|l|l|l|l|l|l|l|l|l|l|l|}
\hline Years & 2007 & 2008 & 2009 & 2010 & 2011 & 2012 & 2013 & 2014 & 2015 & 2016 \\
\hline Cash & 2.71 & 2.01 & 0.65 & 0.032 & 14.72 & 3.22 & 1.75 & 10.76 & 18.65 & 4.20 \\
\hline Current Liabilities & 7.04 & 5.07 & 15.06 & 35.70 & 15.55 & 4.50 & 16.77 & 31.06 & 25.08 & 50.83 \\
\hline Super quick Ratio & 0.385 & 0.397 & 0.043 & 0.0009 & 0.946 & 0.715 & 0.10 & 0.346 & 0.743 & 0.082 \\
\hline
\end{tabular}

Source: Annual Reports of P L Plast Pvt Ltd. from 2006-07 to 2015-2016

Calculated value of $\chi^{2}$ for Super Quick ratio $=3.458$

The Critical value of $\chi^{2}$ at 9 degrees of freedom at $5 \%$ level of Significance is 16.919

Calculated value is less than Critical Value i.e., 3.458<16.919, Hence, $\mathrm{H}_{03}$ is accepted.

Gross working capital turnover ratio of the company as shown in table 5 has varied between 0.603 during 2015 to 1.35 during 2007. It is found in the significance test that Gross working capital turnover ratio is uniform during the period of study.

(Figures in Lakhs)

Table 5: Gross working capital Turnover Ratio

\begin{tabular}{|l|l|l|l|l|l|l|l|l|l|l|}
\hline Years & 2007 & 2008 & 2009 & 2010 & 2011 & 2012 & 2013 & 2014 & 2015 & 2016 \\
\hline Sales & 55.81 & 69.65 & 74.34 & 57.86 & 77.98 & 90.09 & 81.59 & 86.45 & 82.24 & 113.07 \\
\hline Current Assets & 41.32 & 55.37 & 41.92 & 57.41 & 90.49 & 77.51 & 101.72 & 119.75 & 136.30 & 148.92 \\
\hline Ratio & 1.35 & 1.257 & 1.77 & 1.00 & 0.861 & 1.162 & 0.802 & 0.721 & 0.603 & 0.759 \\
\hline
\end{tabular}

Source: Annual Reports of P L Plast Pvt Ltd. from 2006-07 to 2015-2016.

Calculated value of $\chi^{2}$ for Gross Working capital turnover ratio $=0.9906$

The Critical value of $\chi^{2}$ at 9 degrees of freedom at 5\% level of Significance is 16.919

Calculated value is less than Critical Value i.e., 0.9906<16.919, Hence, $\mathrm{H}_{04}$ is accepted.

The net working capital turnover ratio of the company as shown in the table has varied between 0.73 during 2015 and 2.77 during 2009. It is found in the significance test that net working capital turnover ratio is uniform during the period of study.

(Figures in Lakhs)

Table 6: Net Working Capital Turnover Ratio

\begin{tabular}{|l|l|l|l|l|l|l|l|l|l|l|}
\hline Years & 2007 & 2008 & 2009 & 2010 & 2011 & 2012 & 2013 & 2014 & 2015 & 2016 \\
\hline Sales & 55.81 & 69.65 & 74.34 & 57.86 & 77.98 & 90.09 & 81.59 & 86.45 & 82.24 & 113.07 \\
\hline Net Working Capital & 34.28 & 50.3 & 26.86 & 21.71 & 74.74 & 73.01 & 84.95 & 88.69 & 111.22 & 98.09 \\
\hline Ratio & 1.628 & 1.384 & 2.77 & 2.67 & 1.04 & 1.23 & 0.96 & 0.97 & 0.73 & 1.15 \\
\hline
\end{tabular}

Source: Annual Reports of P L Plast Pvt Ltd. from 2006-07 to 2015-2016.

Calculated value of $\chi^{2}$ for Net Working capital turnover ratio $=3.143$

The Critical value of $\chi^{2}$ at 9 degrees of freedom at $5 \%$ level of Significance is 16.919

Calculated value is less than Critical Value i.e., $3.143<16.919$, Hence, $\mathrm{H}_{05}$ is accepted.

The cash turnover ratio of the company as shown in the table 7 has varied between 5.59 during 2015 and 170.7 during 2010. It is found in the significance test that cash turnover ratio is not uniform during the period of study.

Table 7: Cash Turnover Ratio

(Figures in Lakhs)

\begin{tabular}{|l|l|l|l|l|l|l|l|l|l|l|}
\hline Years & 2007 & 2008 & 2009 & 2010 & 2011 & 2012 & 2013 & 2014 & 2015 & 2016 \\
\hline Sales & 55.81 & 69.65 & 74.34 & 57.86 & 77.98 & 90.09 & 81.59 & 86.45 & 82.24 & 113.07 \\
\hline Average Cash Balance & 2.19 & 2.36 & 1.33 & 0.34 & 7.37 & 8.97 & 2.48 & 6.25 & 14.7 & 11.42 \\
\hline Ratio & 25.48 & 29.51 & 55.89 & 170.7 & 10.58 & 10 & 32.89 & 13.83 & 5.59 & 9.9 \\
\hline
\end{tabular}

Source: Annual Reports of P L Plast Pvt Ltd. from 2006-07 to 2015-2016

Calculated value of $\chi^{2}$ for Cash turnover ratio $=607.61$

The Critical value of $\chi^{2}$ at 9 degrees of freedom at $5 \%$ level of Significance is 16.919

Calculated value is greater than Critical Value i.e. $607.61>16.919$, Hence, $\mathrm{H}_{06}$ is rejected.

The inventory turnover ratio of the company as shown in table 8 has varied between 0.948 during 2015 to 5.42 during 2009. It is found in the significance test that cash turnover ratio is uniform during the period of study.

(Figures in Lakhs)

Table 8: Inventory Turnover Ratio

\begin{tabular}{|l|l|l|l|l|l|l|l|l|l|l|}
\hline Years & 2007 & 2008 & 2009 & 2010 & 2011 & 2012 & 2013 & 2014 & 2015 & 2016 \\
\hline Sales & 55.81 & 69.65 & 74.34 & 57.86 & 77.98 & 90.09 & 81.59 & 86.45 & 82.24 & 113.07 \\
\hline Average Inventory & 26.28 & 20.72 & 13.71 & 22.47 & 32.80 & 48 & 79.28 & 87.99 & 86.67 & 86.37 \\
\hline Ratio & 2.12 & 3.36 & 5.42 & 2.58 & 2.37 & 1.87 & 1.02 & 0.98 & 0.948 & 1.309 \\
\hline
\end{tabular}

Source: Annual Reports of P L Plast Pvt Ltd. from 2006-07 to 2015-2016

Calculated value of $\chi^{2}$ for Inventory turnover ratio $=7.865$ 
The Critical value of $\chi^{2}$ at 9 degrees of freedom at $5 \%$ level of Significance is 16.919

Calculated value is less than Critical Value i.e. $7.865<16.919$, Hence, $\mathrm{H}_{07}$ is accepted.

The debtor's turnover ratio of the company as shown in table 9 has varied between 2.28 during 2010 to 11.32 during 2013. It is found in the significance test that Debtors turnover ratio is uniform during the period of study.

Table 9: Debtors Turnover Ratio

(Figures in Lakhs)

\begin{tabular}{|l|l|l|l|l|l|l|l|l|l|l|}
\hline Years & 2007 & 2008 & 2009 & 2010 & 2011 & 2012 & 2013 & 2014 & 2015 & 2016 \\
\hline Sales & 55.81 & 69.65 & 74.34 & 57.86 & 77.98 & 90.09 & 81.59 & 86.45 & 82.24 & 113.07 \\
\hline Average Debtors & 13.01 & 23.87 & 32.20 & 25.36 & 30.43 & 24.13 & 7.20 & 16.20 & 26.60 & 44.65 \\
\hline Ratio & 4.28 & 2.91 & 2.30 & 2.28 & 2.56 & 3.73 & 11.32 & 5.33 & 3.09 & 2.53 \\
\hline
\end{tabular}

Source: Annual Reports of P L Plast Pvt Ltd. from 2006-07 to 2015-2016

Calculated value of $\chi^{2}$ for Debtors turnover ratio $=16.759$

The Critical value of $\chi^{2}$ at 9 degrees of freedom at 5\% level of Significance is 16.919

Calculated value is less than Critical Value i.e., $16.759<16.919$, Hence, $\mathrm{H}_{08}$ is accepted.

The average collection period as shown in table 9 has varied between 32 days during 2013 to 160 days during 2010.

It is found in the significance test that Average collection period is not uniform during the period of study.

(Figures in Lakhs)

Table 9: Average Collection Period

\begin{tabular}{|l|l|l|l|l|l|l|l|l|l|l|}
\hline Years & 2007 & 2008 & 2009 & 2010 & 2011 & 2012 & 2013 & 2014 & 2015 & 2016 \\
\hline Days in a year & 365 & 365 & 365 & 365 & 365 & 365 & 365 & 365 & 365 & 365 \\
\hline Debtors turnover Ratio & 4.28 & 2.91 & 2.30 & 2.28 & 2.56 & 3.73 & 11.32 & 5.33 & 3.09 & 2.53 \\
\hline Average collection period & 85 & 125 & 158 & 160 & 142 & 98 & 32 & 68 & 118 & 114 \\
\hline
\end{tabular}

Source: Annual Reports of P L Plast Pvt Ltd. from 2006-07 to 2015-2016

Calculated value of $\chi^{2}$ for Average collection period $=134$

The Critical value of $\chi^{2}$ at 9 degrees of freedom at 5\% level of Significance is 16.919

Calculated value is greater than Critical Value i.e. $134>16.919$, Hence, $\mathrm{H}_{09}$ is rejected.

\section{Conclusion}

It was found that inventory occupied first place followed by debtors as a percentage of current assets in P L Plast Pvt Ltd. during the period of study. We can found that the firm attained credit worthiness after ten years of its inception.

It was reflected in increased creditors and short term borrowings in the second half of the study period. Current ratio of the company was relatively high which indicates that though liquidity in the company is high and profitability might have reduced to some extent. Current ratio, cash turnover ratio and average collection periods are not uniform during the period of study and showed wide fluctuations. Collection of debts and cash utilization was poorly done in the company during the period of study. Quick ratio, super quick ratio, Gross working turnover ratio, net working capital turnover ratio, Inventory turnover and debtor turnover ratios are uniform during the period of study.

\section{Reference}

[1]. Mishra, R.K., "Problems of Working Capital - with Reference to Selected Public Undertakings in India", Somaiya Publication, Bombay, 1975.

[2]. Suk, H., Seung, H. and Rewland, "Working Capital Practices of Japanese Firms in the US", Financial Practice and Education, Spring - Summer, Vol.2, No.1, 1992,pp. 89-92.

[3]. Sivarama PR, "Working Capital Management in Indian Paper Industry", Unpublished Thesis, Nagarjuna University, Nagarjuna Nagar, Guntur, 1999.

[4]. Reddy, S.H., "Working Capital Management in Small Scale Industries - A Case Study of Cuddapah District", Doctoral Dissertation, Sri Venkateswara Univeristy, Tirupati, 2000.

[5]. Ghosh SK and Maji SG, "Utlization of Current Assets and Operating Profitability: An Empirical Study on Cement and Tea Industries in India", Indian Journal of Accounting, IAA, 2003, pp.81-91.

[6]. Bardia SC, "Liquidity Management: A Case Study of Steel Authority of Indian Ltd.", The Management Accountant, ICWAI, June, 2004, pp.463 - 467.

[7]. Prof. B.P. Singh, "Working Capital Management and Profitability in the IT and Telecom Industry in India", Indian Journal of Finance, Vol.6.No.3, 2004, pp 54-61.

[8]. Pasupathi “Working Capital Management of Indian Automobile Industry”, Finance India, vol-XXVI, No.1, 2004, pp. 163-170.

[9]. Utkarsh Goel et al., "Impact of Corporate Governance Practices on Working Capital Management Efficiency: A structural Equation Modelling Approach", Indian Journal of Finance, Vol: 9, No-1, 2015, pp. 38-48.

[10]. S. Selvanayaki et al., "Working Capital Management in modern rice milling firms at kangayam Tamilnadu", Indian Journal of Finance, vol:9, No:2, 2015, pp. 17-24. 